\title{
Protein Turnover in Chlorella fusca var. vacuolata: Detection of a Rapidly Degraded Class of Protein in Growing and Non-growing Cells
}

\author{
By C. F. THURSTON AND L. RICHARDS* \\ Department of Microbiology, Queen Elizabeth College, Campden Hill Road, \\ London W8 7 AH
}

(Received 26 October 1979)

\begin{abstract}
Chlorella fusca var. vacuolata protein was labelled by incorporation of ${ }^{14} \mathrm{C}$-labelled leucine or tyrosine. On subsequent incubation with unlabelled amino acid in otherwise nitrogenfree medium, radioactive amino acid accumulated in the medium as a consequence of intracellular protein degradation (turnover). The kinetics of loss of label from protein was first order with two major components. By varying the period of incorporation of ${ }^{14} \mathrm{C}$ labelled amino acid into protein of growing cells, it was deduced that about $8 \%$ of protein was degraded at about $20 \% \mathrm{~h}^{-1}$ in growing cells. The relative size of the 'unstable' fraction decreased at the onset of nitrogen starvation. The remaining cell protein was degraded much more slowly during nitrogen starvation and may have been essentially stable in growing cells.
\end{abstract}

\section{INTRODUCTION}

Intracellular protein turnover cannot be measured easily in some eukaryotic microorganisms such as Chlorella fusca var. vacuolata. Measurements of the overall rate of protein degradation using isotope exchange from water have been presented in the preceding paper (Richards \& Thurston, 1980 b). These data show that the overall rate of protein degradation in nitrogen-starved $C$. fusca is of the order of 0.5 to $3.5 \% \mathrm{~h}^{-1}$, and that the overall rate of protein degradation during growth is apparently too small to be estimated reliably. Isotope exchange from water was used to measure overall rates of protein degradation because $C$. fusca cells do not readily exchange amino acids into the surrounding medium (Richards \& Thurston, $1980 a$ ). Growing cells quantitatively retain intracellular pools of $\left[{ }^{14} \mathrm{C}\right]$ leucine or $\left[{ }^{14} \mathrm{C}\right]$ tyrosine when a large excess of the same amino acid is added to the medium, whereas nitrogen-starved $C$. fusca cultures show a large, but incomplete, exchange of both amino acids. As a consequence, measurements of the loss of radioactivity from $C$. fusca cells prelabelled with $\left[{ }^{14} \mathrm{C}\right]$ leucine or $\left[{ }^{14} \mathrm{C}\right]$ tyrosine, when suspended in nitrogen-free medium containing an unlabelled amino acid trap, may underestimate the rate of protein degradation because a proportion of the released radioactive amino acid may be reincorporated into cell protein.

Although this sort of experiment cannot be used in isolation for reliable measurement of the rate at which cell proteins are degraded, it can be used, as reported here, to distinguish classes of protein with widely different average rates of degradation and to estimate their relative amounts. 


\section{METHODS}

Organism and culture conditions. Chlorella fusca var. vacuolata (Culture Collection of Algae and Protozoa, Cambridge, strain no. 211-8P) was grown autotrophically at $25^{\circ} \mathrm{C}$ in a mineral salts medium, aerated with air supplemented with $0.5 \%(\mathrm{v} / \mathrm{v}) \mathrm{CO}_{2}$ under continuous illumination as described by Richards \& Thurston $(1980 a)$. Nitrogen-free medium differed from growth medium only by the omission of $\mathrm{NH}_{4} \mathrm{NO}_{3}$.

Experimental conditions. Experiments were conducted with $100 \mathrm{ml}$ volumes of medium containing $5.5 \times 10^{8}$ cells taken from exponentially growing cultures and incubated for $1.5 \mathrm{~h}$ prior to the start of an experiment. Conditions of temperature, illumination and aeration were as described above for growth of the organisms. With the exception of one experiment for which conditions are given in the legend to Fig. 3, cell protein was labelled by adding either L-[U-14 $\mathrm{C}]$ leucine or L-[U-14 $\mathrm{C}]$ tyrosine to give a concentration of $0.2 \mu \mathrm{m}$ at a specific activity of $335 \mathrm{Ci} \mathrm{mol}^{-1}\left(12.4 \mathrm{TBq} \mathrm{mol}^{-1}\right)$. The time allowed for incorporation of radioactive amino acid was varied and is given for each experiment in the figure legends. To stop incorporation, cells were centrifuged from the medium, washed twice in nitrogen-free medium and resuspended in nitrogenfree medium containing $1 \mathrm{~mm}$ L-leucine or L-tyrosine to correspond with the radioactive amino acid used. The harvesting and resuspension procedure was accomplished as quickly as possible and followed immediately by the removal of samples which constituted the start of the time course of measurement of protein degradation.

Leucine and tyrosine at $1 \mathrm{~mm}$ concentration did not support growth in otherwise nitrogen-free medium (results not shown), nor did they affect the growth rate of autotrophic cultures (Richards, 1978).

When radioactive leucine or tyrosine was incorporated into $C$. fusca cells, trichloroacetic acid-soluble radioactivity was detected only as the same amino acid as added, throughout the experiments described (Richards, 1978), and there was no measurable catabolism of either amino acid (results not shown).

Treatment of samples. Radioactivity in $0.1 \mathrm{ml}$ samples of cell suspension was measured at intervals during the experiment to determine the total amount of radioactive amino acid incorporated and so that correction could be made for change in cell concentration due to evaporation which occurred in some experiments. These samples were made up to $1 \mathrm{ml}$ with distilled water and counted after addition of $15 \mathrm{ml}$ scintillation fluid [toluene/Triton X-100/2-(4'-tert-butylphenyl)-5-(4'-biphenylyl)-1,3,4-oxadiazole (butyl-PBD) (100: $50: 1, \mathrm{v} / \mathrm{v} / \mathrm{w})]$. Radioactivity in protein was measured in $1 \mathrm{ml}$ samples taken in quadruplicate, which were immediately mixed with $1 \mathrm{ml} 10 \%(\mathrm{w} / \mathrm{v})$ trichloroacetic acid in methanol. After $5 \mathrm{~min}$ at $55^{\circ} \mathrm{C}$ the samples were filtered through $2.5 \mathrm{~cm}$ diam. glass-fibre filters (Whatman $\mathrm{GF} / \mathrm{C}$ ) and the filters were washed twice with $2.5 \mathrm{ml}$ methanol. The filters were dried in a desiccator and counted in $10 \mathrm{ml}$ toluene/butyl-PBD $(100: 1, \mathrm{v} / \mathrm{w})$. All samples were counted at $10^{\circ} \mathrm{C}$ for $20 \mathrm{~min}$ in a Beckman LS-233 scintillation spectrometer and c.p.m. were converted to d.p.m. using an external standard channels ratio method.

Analysis of data. The average of each set of values for radioactivity in protein was expressed as a proportion of the radioactivity in protein at the start of the chase period. The figures show $\log _{10}(x=$ relative radioactivity in protein) versus time (h). The lines drawn through the data points are curves for the equation

$$
x=x_{1} \exp \left(-k_{1} t\right)+x_{2} \exp \left(-k_{2} t\right)
$$

where the values for the four constants have been chosen by trial and error to give the best fit to the data points. Hence, the lines represent the decay of two components $X_{1}$ and $X_{2}$ (where $x_{1}$ and $x_{2}$ are the relative proportions of these, and $\left.x_{1}+x_{2}=1 \cdot 0\right)$ with specific decay rates $k_{1}$ and $k_{2}$, respectively.

If the rate of synthesis of all proteins is the same, the proportions of radioactivity in the two classes of protein $\left(\mathbf{X}_{1}, \mathbf{X}_{2}\right)$ will equal the actual proportions of these classes of protein. If, on the other hand, the average rate of synthesis of the proteins composing one class differs from that of the other, the proportion of radioactivity in the two classes will be dependent upon the duration of the period during which radioactivity was incorporated into protein - the class with the higher average rate of synthesis acquiring a higher proportion of incorporated radioactivity, the shorter the period of incorporation. The following procedure was used to determine the approximate proportions of two classes of protein with different average rates of synthesis (and different average rates of degradation).

Definition of symbols: for protein of class $l, x^{l}$ is the amount of protein, $r^{l}$ is the amount of radioactivity in protein, $\alpha^{l}$ is the average rate of synthesis of protein, and $\beta^{l}$ is the average rate of degradation of protein; $x^{s}, r^{s}, \alpha^{s}$ and $\beta^{s}$ are the corresponding quantities for a second class of protein, $s$.

For an exponentially growing system with constant proportions of the two classes of protein (i.e. in balanced growth):

$$
\begin{aligned}
& \frac{\mathrm{d} r}{\mathrm{~d} t}=\alpha x-\beta r \\
& \frac{\mathrm{d} x}{\mathrm{~d} t}=(\alpha-\beta) x
\end{aligned}
$$




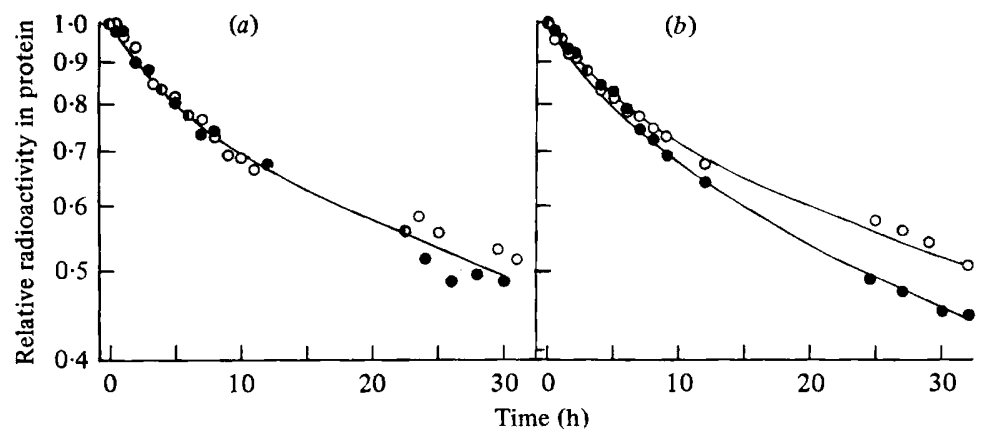

Fig. 1. Intracellular protein degradation in $C$. fusca. Exponentially growing cultures were labelled with $200 \mathrm{nM}{ }^{14} \mathrm{C}$-labelled amino acid $\left(250 \mathrm{Ci} \mathrm{mol}^{-1}, 9.25 \mathrm{TBq} \mathrm{mol}{ }^{-1}\right)$ for $0.5 \mathrm{~h}$; cells were then washed and resuspended in nitrogen-free medium containing $1 \mathrm{~mm}$ unlabelled amino acid. Radioactivity in protein is expressed as a proportion of the amount present at the start of the chase period.

(a) Radioactivity was supplied as $\mathrm{L}-\left[{ }^{14} \mathrm{C}\right]$ leucine. The initial radioactivity in protein was $0.011 \mu \mathrm{Ci} \mathrm{ml}^{-1}\left(0.41 \mathrm{kBq} \mathrm{ml}^{-1}\right)$ in one experiment (O) and $0.0035 \mu \mathrm{Ci} \mathrm{ml}^{-1}\left(0.130 \mathrm{kBq} \mathrm{ml}^{-1}\right)$ in another $(O)$. The line drawn through the data points is for the equation $x=x_{1} \exp \left(-k_{1} t\right)$ $+x_{2} \exp \left(-k_{2} t\right)$ with the values $0.23,0.77,0.20$ and 0.015 for the constants $x_{1}, x_{2}, k_{1}$ and $k_{2}$, respectively.

(b) Radioactivity supplied as $\mathrm{L}-\left[{ }^{14} \mathrm{C}\right]$ tyrosine. One experiment $(O)$ was performed at $25^{\circ} \mathrm{C}$, and the initial radioactivity in protein was $0.0083 \mu \mathrm{Ci} \mathrm{ml}^{-1}\left(0.307 \mathrm{kBq} \mathrm{m}^{-1}\right)$; the line drawn is for the same equation as in $(a)$, with values for the constants of $0.20,0.80,0.20$ and 0.015 , respectively. Another experiment $(\Theta)$ was performed at $30^{\circ} \mathrm{C}$, and the initial radioactivity in protein was $0.0046 \mu \mathrm{Ci} \mathrm{ml}^{-1}\left(0 \cdot 170 \mathrm{kBq} \mathrm{ml}^{-1}\right)$; the line drawn through the points is for values of the constants of $0.23,0.77,0.20$ and 0.018 , respectively.

Integrating equation (2) and substituting in (1) gives

$$
\frac{\mathrm{d} r}{\mathrm{~d} t}=\alpha x_{0} \exp [(\alpha-\beta) t]-\beta r
$$

where $x_{0}$ is the amount of protein at $t=0$ and for which the solution is

$$
r=x_{0}\{\exp [(\alpha-\beta) t]-\exp (-\beta t)\}
$$

Hence, for two classes of protein the amount of one $\left(x^{l}\right)$ as a proportion of the other $\left(x^{s}\right)$ is given by

$$
x_{0}^{l}=\frac{x_{0}^{s} r^{l}}{r^{s}}\left\{\frac{\exp \left[\left(\alpha^{s}-\beta^{s}\right) t\right]-\exp \left(-\beta^{s} t\right)}{\exp \left[\left(\alpha^{l}-\beta^{l}\right) t\right]-\exp \left(-\beta^{l} t\right)}\right\}
$$

It should be noted that values for $\alpha^{l}$ and $\alpha^{s}$ are not required for derivation of the relative amounts of $x^{l}$ and $x^{s}$ as, for a population of cells in balanced growth, $\alpha^{l}-\beta^{l}=\alpha^{s}-\beta^{s}=\mu$, the specific growth rate. For all growing cultures in experiments reported in this paper the specific growth rate was $0.087 \mathrm{~h}^{-1}$.

Radiochemicals. These were obtained from The Radiochemical Centre, Amersham.

\section{RESULTS AND DISCUSSION}

\section{Degradation of protein labelled with $\left[{ }^{14} \mathrm{C}\right]$ leucine}

Figure 1 $(a)$ shows the results of two typical experiments where, after $0.5 \mathrm{~h}$ labelling during growth, loss of $\left[{ }^{14} \mathrm{C}\right]$ leucine from protein was measured under nitrogen-free conditions. The line drawn through the data points represents the release of $23 \%$ of protein at $0 \cdot 2 \mathrm{~h}^{-1}$ with the remaining $77 \%$ of protein radioactivity being lost at $0.015 \mathrm{~h}^{-1}$. The values for degradation rates are likely to be underestimates as the exchange of radioactive leucine into the medium was not rapid (Richards \& Thurston, 1980a), with the consequence that a proportion of radioactive amino acid may have been reincorporated into protein. Nevertheless, it is apparent that a proportion of $C$. fusca protein had an average degradation rate which was more than 10-fold greater than that of the bulk of cell protein. It is necessary to consider an alternative conclusion, that is, that following transfer to nitrogen-free medium there was a high rate of protein degradation for about $10 \mathrm{~h}$ which was independent of the protein 


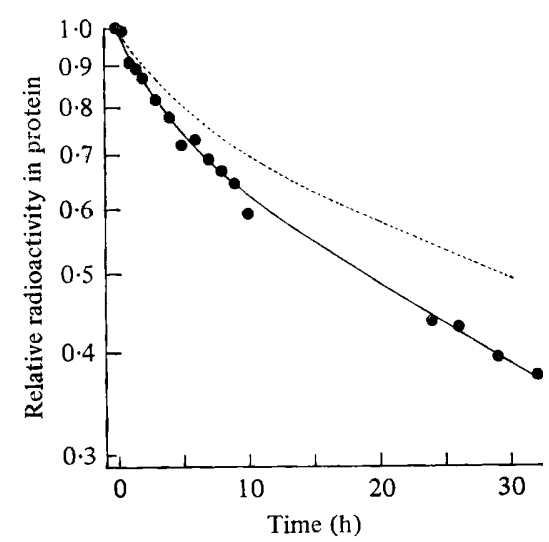

Fig. 2

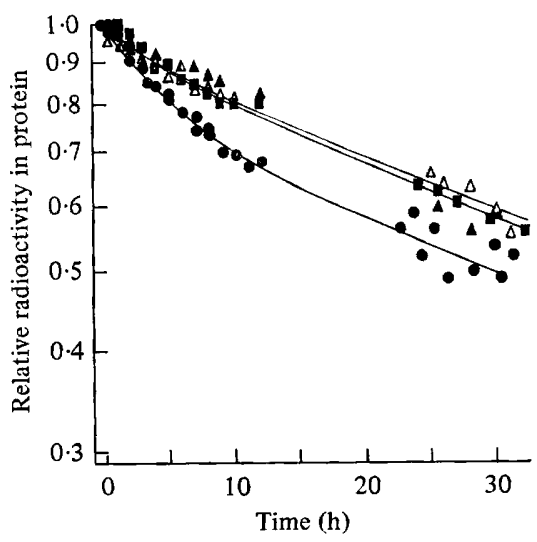

Fig. 3

Fig. 2. Degradation of $C$. fusca protein synthesized during nitrogen-starvation. A $C$. fusca culture was transferred to nitrogen-free medium and after $1.5 \mathrm{~h}$ incubation was supplied with $\left[{ }^{14} \mathrm{C}\right]$ leucine for $0.5 \mathrm{~h}$, as described in the legend to Fig. 1. Intracellular degradation was followed after washing and resuspension in nitrogen-free medium containing $1 \mathrm{~mm}-\mathrm{L}-$ leucine. The initial radioactivity in protein was $0.0024 \mu \mathrm{Ci} \mathrm{ml}^{-1}\left(0.089 \mathrm{kBq} \mathrm{ml}^{-1}\right)$. The line drawn through the data points is for values of $0.25,0.75,0.25$ and 0.022 for the constants $x_{1}, x_{2}, k_{1}$ and $k_{2}$, respectively. The dashed line is from Fig. 1(a) for comparison.

Fig. 3. Effect of the duration of the period of labelling on the kinetics of release of $\left[{ }^{14} \mathrm{C}\right]$ leucine from $C$. fusca protein: 0 , data from Fig. $1(a) ; \boldsymbol{\square}$, data from an experiment which differed only in that $\left[{ }^{14} \mathrm{C}\right]$ leucine was incorporated for $22.3 \mathrm{~h}$ in a $200 \mathrm{ml}$ culture volume giving $0.0063 \mu \mathrm{Ci} \mathrm{ml}{ }^{-1}$ $\left(0.233 \mathrm{kBq} \mathrm{ml}^{-1}\right)$ radioactivity in protein at the start of the chase period; $\boldsymbol{\Delta}$, data from a similar experiment where the period of labelling was $64 \mathrm{~h}$ and the radioactivity in protein at the start of the chase period was $0.0072 \mu \mathrm{Ci} \mathrm{m}^{-1}\left(0.266 \mathrm{kBq} \mathrm{ml}^{-1}\right) ; \triangle$, data from a culture labelled with $50 \mu \mathrm{M}-\mathrm{L}-\left[{ }^{14} \mathrm{C}\right]$ leucine $\left(2 \mathrm{Ci} \mathrm{mol}^{-1}, 74 \mathrm{GBq} \mathrm{mol}^{-1}\right)$ for $64 \mathrm{~h}$ in which the radioactivity in protein at the start of the chase period was $0.059 \mu \mathrm{Ci} \mathrm{m}^{-1}\left(2.18 \mathrm{kBq} \mathrm{ml}^{-1}\right)$. The lines drawn through the points are from the equation and with the constants specified in Table 1.

species into which the radioactive amino acid had been incorporated. In Fig. 2, protein degradation is shown for a $C$. fusca culture labelled with $\left[{ }^{14} \mathrm{C}\right]$ leucine for $0.5 \mathrm{~h}$ as before, but here the amino acid was incorporated in nitrogen-free medium after $1.5 \mathrm{~h}$ of prior nitrogen starvation. The duration of the period during which radioactivity was lost rapidly from protein was not reduced, demonstrating that nitrogen starvation did not produce a short-lived increase in the overall rate of protein degradation. Rather the proportion of label in the 'unstable' fraction was marginally increased. The rate of degradation for both fractions was greater; this was not a consequence of a change in efficiency of the cold trap as the degradation of protein was observed under essentially the same conditions in the experiments shown in Figs 1 and 2. It appears, therefore, that there was an increase in the synthesis of relatively rapidly degraded proteins within both the rapidly and slowly degraded classes of protein when $C$. fusca cells were nitrogen-starved.

\section{Degradation of protein labelled with $\left[{ }^{14} \mathrm{C}\right]$ tyrosine}

When protein was labelled with $\left[{ }^{14} \mathrm{C}\right]$ tyrosine rather than $\left[{ }^{14} \mathrm{C}\right]$ leucine the kinetics of protein degradation were the same (Fig. $1 b$ compared with Fig. $1 a$ ). Figure $1(b)$ also shows an apparent increase in rates of protein degradation when the temperature of incubation of C. fusca cultures was increased from 25 to $30^{\circ} \mathrm{C}$. The increases in apparent rates could alternatively be a consequence of a reduction in amino acid recycling with increase in temperature. 


\section{Table 1. Degradation of protein labelled with $\left[{ }^{14} \mathrm{C}\right]$ leucine: analysis of data presented in Fig. 3}

The distribution of radioactivity and degradation rates are the constants for the equation $x=x_{1} \exp \left(-k_{1} t\right)+x_{2} \exp \left(-k_{2} t\right)$ which was used to fit the lines drawn through the data points in Fig. 3, as described in Methods. The proportion of protein comprising the 'unstable' fraction was derived using equation (5) (see Methods). For (a), it was assumed that degradation of protein in the stable fraction was negligible in growing cells $\left(\beta^{s}=0\right)$. For $(b)$, protein in the stable fraction was assumed to be degraded at the same rate during growth as was observed during nitrogen starvation $\left(\beta^{s}=0.015 \mathrm{~h}^{-1}\right)$.

\begin{tabular}{|c|c|c|c|c|c|c|}
\hline \multirow{3}{*}{$\begin{array}{l}\text { Time of } \\
\text { incorporation } \\
\text { (h) }\end{array}$} & \multicolumn{2}{|c|}{ 'Unstable' fraction } & \multicolumn{2}{|c|}{ 'Stable' fraction } & \multirow{2}{*}{\multicolumn{2}{|c|}{$\begin{array}{c}\text { Calculated proportion } \\
\text { of protein comprising } \\
\text { the 'unstable' fraction } \\
(\%)\end{array}$}} \\
\hline & \multirow{2}{*}{$\begin{array}{c}\text { Proportion } \\
\text { of } \\
\text { incorporated } \\
\text { radioactivity } \\
(\%)\end{array}$} & \multirow{2}{*}{$\begin{array}{c}\text { Degradation } \\
\text { rate } \\
\left(\mathrm{h}^{-1}\right)\end{array}$} & \multirow{2}{*}{$\begin{array}{c}\text { Proportion } \\
\text { of } \\
\text { incorporated } \\
\text { radioactivity } \\
(\%)\end{array}$} & \multirow{2}{*}{$\begin{array}{c}\text { Degradation } \\
\text { rate } \\
\left(\mathrm{h}^{-1}\right)\end{array}$} & & \\
\hline & & & & & (a) & (b) \\
\hline 0.5 & 23 & $0 \cdot 20$ & 77 & 0.015 & 8.7 & 9.0 \\
\hline $22 \cdot 3$ & 9 & $0 \cdot 20$ & 91 & 0.015 & $7 \cdot 8$ & $8 \cdot 2$ \\
\hline $64 \cdot 0$ & 8 & $0 \cdot 20$ & 92 & 0.012 & 8.0 & 8.0 \\
\hline
\end{tabular}

\section{Relative size of the 'unstable' and 'stable' fractions of C. fusca protein}

The pattern of loss of radioactivity from protein varied in a set of $C$. fusca cultures where $\left[{ }^{14} \mathrm{C}\right]$ leucine was incorporated during growth for different periods of time (Fig. 3). As the incorporation period increased the proportion of radioactivity in the 'unstable' fraction decreased. This result could only be obtained if the 'unstable' fraction had a greater specific rate of synthesis than the rest of cell protein, which, in turn, implies that the 'unstable' fraction was degraded in growing cells so that the net rate of increase in the amount of these proteins was the same as for other proteins, conserving the constant protein composition of a population of cells in balanced growth. From the data in Fig. 3, the proportion of total protein constituting the 'unstable' fraction was calculated using equation (5) (Table 1). This requires a number of assumptions. The first assumption is that the incorporation of radioactivity was from an instantaneously filled pool of constant specific activity for the duration of the period of labelling. Whilst the system may not have conformed precisely to this behaviour, it probably approximated to it reasonably well.

Our results for the uptake of leucine and tyrosine showed that the precursor pools for protein synthesis filled quickly in relation to periods of incorporation of at least $0.5 \mathrm{~h}$ (Richards \& Thurston, 1980 a). These results also showed short-term incorporation kinetics which were consistent with uptake from a pool of constant specific activity for periods in excess of $0.5 \mathrm{~h}$ with the same concentration of amino acid as used in these experiments $(200 \mathrm{nM})$. It is less certain that this concentration of amino acid is sufficient to maintain constant pool specific activity for $64 \mathrm{~h}$, which was the longest period of incorporation used, but increasing the concentration of leucine supplied 250 -fold did not significantly alter the kinetics of protein degradation (Fig. 3).

The second assumption concerns the value assigned to the rate of degradation of the ' unstable' protein fraction during growth $\left(\beta^{l}\right)$. In Table 1 the proportion of protein comprising the 'unstable' fraction was calculated using equation (5) and the observed value for $\beta^{l}$ for degradation during nitrogen starvation. This gave similar results for all three periods of labelling, which was not found if the value used for $\beta^{2}$ was either halved or doubled, and suggests that the estimate was of the correct order of magnitude.

The calculation also depends on an assumed value for the degradation of the 'stable' fraction. We have no data which unequivocally showed that this protein was degraded at all in growing cells. Consequently, values used were $\beta^{s}=0$ (this protein fraction was stable during growth) and $\beta^{s}=0.015$ (the degradation rate during growth was the same as the 
apparent rate during nitrogen starvation). These represent a minimum value and a probable maximum value, but, most significantly, the calculated proportion of 'unstable' protein is relatively insensitive to this component, particularly as the system tended towards saturation after the longest period of labelling. The similarity of the values calculated (Table 1) with widely different incorporation times supports the notion that the 'unstable' fraction constitutes about $8 \%$ of total protein, but we would emphasize that this is an approximate value only.

Equally, it is worth reiterating that although the fit of our data to the two-component first-order decay model is good, it is more realistic to regard the classes of protein as heterogeneous assemblies where the observed decay rates are average values of a range of different individual rates.

If equation (5) is applied to the data in Fig. 2, it appears that the 'unstable' protein fraction was $3.0 \%$ of total protein if the value of $\left(\alpha^{l}-\beta^{l}\right)$ was set to zero. This is not a valid procedure, however, as although total protein remains constant throughout the first $24 \mathrm{~h}$ of nitrogen starvation, the proportion of protein in the 'unstable' fraction must be declining rapidly from the $8 \%$ value found in growing cells. Thus, the analysis showed that the proportion of 'unstable' protein was decreasing during the first few hours of nitrogen starvation but could not show by how much, as there was no reliable way of determining the specific rate of synthesis of this class of protein in such a transient state.

\section{Significance of the presence of rapidly turned over proteins in growing cells}

We have previously been unsuccessful in attempts to demonstrate a finite rate of intracellular protein degradation in growing C. fusca (Richards \& Thurston, 1980 b). The data presented in this paper indicate that although only a small proportion of protein $(8 \%)$ may be subject to degradation during growth, the likely average rate of degradation (of the order of $0.2 \mathrm{~h}^{-1}$ ) is sufficient to give an overall rate of turnover of the order of $0.01 \mathrm{~h}^{-1}$. As the maximum specific growth rate of the organism is $0.087 \mathrm{~h}^{-1}$, replacement of degraded protein must account for about one-tenth of total protein synthesis during growth. The identity of the species of protein that constitute this labile class in growing cells is unknown. Two types of protein are likely to contribute to the rapidly degraded class: first, defective proteins, as has frequently been suggested (Goldberg \& St John, 1976) and secondly, some enzyme proteins. In Chlorella sorokiniana, NADP-specific glutamate dehydrogenase is subject to turnover at about $0.4 \mathrm{~h}^{-1}$ in fully induced cultures (A. T. Yeung, N. F. Bascomb \& R. R. Schmidt, personal communication); this may well prove to be typical of a number of key regulatory enzymes, although we have shown elsewhere that isocitrate lyase is stable in induced cultures (Dunham \& Thurston, 1978).

We are very grateful for help with the mathematics from Dr P. T. Saunders. L. R. thanks the Science Research Council for a studentship.

\section{REFERENCES}

Dunham, S. M. \& Thurston, C. F. (1978). Control of isocitrate lyase synthesis in Chlorella fusca var. vacuolata. Rate of enzyme synthesis in the presence and absence of acetate measured by ${ }^{35} \mathrm{~S}$ methionine labelling and immunoprecipitation. Biochemical Journal 176, 179-185.

Goldberg, A. L. \& ST John, A. C. (1976). Intracellular protein degradation in mammalian and bacterial cells, Part II. Annual Review of Biochemistry 45, 747-803.

RICHARDS, L. (1978). Measurement of intracellular protein turnover in the green alga Chlorella. Ph.D. thesis, University of London.

Richards, L. \& Thurston, C. F. (1980a). Uptake of leucine and tyrosine and their intracellular pools in Chlorella fusca var. vacuolata. Journal of General Microbiology 121, 39-47.

Richards, L. \& Thurston, C. F. (1980b). Protein turnover in Chlorella fusca var. vacuolata: measurement of the overall rate of intracellular protein degradation using isotope exchange with water. Journal of General Microbiology 121, 49-61. 